\title{
Agreed Fundamental Rules Relating to Sharia Ruling and Their Jurisprudence Applications
}

\author{
Dr. Mohammad Shareef Mustafa Isteti \\ Associate Professor \\ World Islamic Sciences and Education University \\ Faculty of Figh Hanafi, Amman \\ Jordan
}

\begin{abstract}
This paper addresses agreed fundamentals between fundamentalists, relating to sharia ruling with an explanation of each vocabulary base, and the statement of the overall meaning, and one jurisprudence application to each rule. This paper stated six rules. This paper has shown that there were agreed fundamentals between fundamentalists, and this is an alert for students of Shari school to be aware of when they are reading fundamentalist rules, to distinguish between what was agreed, and what was disagreed, as well as this paper contributes to the development of jurisprudential talent of students of Islamic Sharia, through explaining the vocabularies of the rules, the statement of their meaning, and the jurisprudential applications on the fundamentalism rules.
\end{abstract}

Keywords: Fundamentals, Fundamentalist consensus, Jurisprudence application

\section{Introduction}

All praise is due to Allah and peace and blessings are upon his honorable Prophets and Messengers, Muhammad bin Abdullah, and his family and his companions divine, who marched on their way to the Day of Judgment. The provisions of the rules are holistic fundamentalist reached out to devise legal provisions of the detailed evidence, or Weighting between opposing doctrinal statements. Knowing these rules is one of the core of understanding religion, these rules have been derived from sources, the first is Quran, the second is Sunnah, and the third is consensus, so I liked that my research addresses some of the rules of agreed fundamentals, related to Sharia Ruling, to show that the fundamental rules, include what is agreed, and what is disagreed.

\section{Research Importance}

This research derives its significance by drawing attention to the rules of fundamentalism, that is the core of the principles of jurisprudence, and the rest of its issues and researches are a clarification for these rules, some of which is agreed, and some of which is disagreed. The agreed rules were considered as axioms, and the disagreed rules were dealt based on the knowledge of those who say the rule, and who contrary to it, with the evidence of each team, and discussing it until they agreed on one.

\section{Research Problem and Questions}

This research tries to answer the following questions:

1- Is there a correlation between consensus and the fundamental rules?

2- How we can help the students to know the agreed fundamental rules?

3- What is the fundamentalists' effort in clarifying the agreed fundamentalist rules?

4- How we can develop the jurisprudential and fundamental talent of Shari school students?

\section{Research Aims:}

This research aims to achieve the following objectives:

1- The meaning of fundamental rules.

2- The division of fundamental rules to agreed and disagreed rules.

3- The Fundamental rules vocabulary meanings that featured in the research.

4- The Fundamental rules total meanings that featured in the research.

5- Jurisprudential applications on the fundamental rules that featured in the research. 


\section{Previous Studies:}

This type of study has not singled out - as I know - but (Mustafa Bo Aqel) in his book "fundamentalists consensus: collect and study", which was originally an academic thesis introduced to the Faculty of Islamic Sciences at the University of Algiers, and included an introductory chapter and five sections. The introductory chapter addressed authoritative consensuses, its bases, divisions, areas of consensus, and fundamentalists care of it.

The first section addressed consensuses related to provisions evidences (total evidences).

The second section addressed consensuses related to semantics.

The third section addressed consensuses related to Islamic ruling and supplies.

The fourth section addressed consensuses related to conflict, weighting and copies.

The fifth section addressed consensuses related to diligence, imitation and religious opinion.

The number of consensuses mentioned were (212), (125) of them were true, and approach that was taken was mentioning "consensus of .....", then mentioning who agreed from the fundamentalists, and who disagreed with that if there is, then discussing and weighting, with no mention of practical examples of the issues mentioned.

There are many advantages of this book, including:

1. It cautioned that there are agreed fundamentalist issues and rules.

2- It is a must to make sure before you say that this issue or rule is agreed.

It was shown that the number of consensuses that is likely agreed were (125) out of (212) consensuses.

This research has added the following matters:

1- Attention that the fundamentalism rules including what is the agreed, and what is disagreed.

2- Explaining the vocabularies of six agreed fundamental rules.

3- Explaining of the total meaning of six agreed fundamental rules.

4- Attention to build branches on assets, by mentioning one jurisprudential application on each agreed fundamental rule.

\section{Research Methodology}

The research depended on the following approaches:

1- Inductive approach: through extrapolation and following the agreed fundamental rules.

2-Descriptive approach: through the explanation of the total meaning of six agreed fundamental rules, with an example of one jurisprudential application on each rule.

\section{Research Plan}

The research included an introductory, a primary section, and a conclusion.

The introductory addressed research importance and aims, previous studies, and research methodology.

The primary section addressed the fundamental rules related to Shari Ruling, it included six demands:

Demand (1): addressed the rule: Sufficiency duty is brought down if some legal competents do it, it includes four branches:

Branch (1): Who agreed the consensus of the rule?

Branch (2): Explaining the vocabularies of the rule.

Branch (3): The total meaning of the rule.

Branch (4): An application of the rule.

Demand (2): addressed the rule: Favored actions which are optional are obedience, it includes four branches:

Branch (1): Who agreed the consensus of the rule?

Branch (2): Explaining the vocabularies of the rule.

Branch (3): The total meaning of the rule.

Branch (4): An application of the rule.

Demand (3): addressed the rule: Continuation of assignment to the Day of Resurrection, it includes four branches:

Branch (1): Who agreed the consensus of the rule?

Branch (2): Explaining the vocabularies of the rule.

Branch (3): The total meaning of the rule.

Branch (4): An application of the rule.

Demand (4): addressed the rule: The infidels do not assigned after their Islam of the acts of their infidelity, it includes four branches:

Branch (1): Who agreed the consensus of the rule?

Branch (2): Explaining the vocabularies of the rule.

Branch (3): The total meaning of the rule. 
Branch (4): An application of the rule.

Demand (5): addressed the rule: The initiator to the ordered manners act in the absolute command comes out the custody of assignment, it includes four branches:

Branch (1): Who agreed the consensus of the rule?

Branch (2): Explaining the vocabularies of the rule.

Branch (3): The total meaning of the rule.

Branch (4): An application of the rule.

Demand (6): addressed the rule: It is not permissible for the assigned person to delay the ordered act to the time, that if it had been done, he would have exceeded it, it includes four branches:

Branch (1): Who agreed the consensus of the rule?

Branch (2): Explaining the vocabularies of the rule.

Branch (3): The total meaning of the rule.

Branch (4): An application of the rule.

The conclusion addressed the most important results of the research.

\section{The primary section}

\section{Fundamentalist Rules related to Sharia Ruling}

It has six demands:

\section{Demand (1)}

\section{The first rule: Sufficiency duty is brought down if some legal competents do it.}

It includes four branches:

\section{Branch (1): Who agreed the consensus of the rule?}

A number of fundamentalists recounted consensus on this rule, including Al-Zarkashi, he said: "They differed as to whether sufficiency duty regards to all or some people, in two sayings, with the agreement that it is being dropped out if it is done by some" ${ }^{(1)}$.

\section{Branch (2): Explaining the vocabularies of the rule.}

Imposition: imposition in language: Ibn Zakaria said: "it is a true origin indicates an effect in something else of the slitting or other. It is also: to derive the premise that God asked. This is called because it has features and limits"(2). Conventionally, there are two trends in the definition of the term, namely:

The first trend: they are the majority of scholars, who see that the imposition synonymous to duty. Ibn al-Najjar said: " it is narrated by the hadeeth, which is obligatory according to sharia, that is, in the knowledge of sharia on the Saheeh, Shafi'i and more" ${ }^{(3)}$. And they knew it with many definitions, and perhaps the most precise of them: "it is in law, what slanders who leaving it with no intention at all"(4). The second trend: they are Hanafis, who says that the imposition and duty are two different words, they define the imposition that: "What is proved by a definitive evidence not suspicious of $^{\prime(5)}$. In other words, what has been proved by definitive evidence in the Quran or Sunnah is the obligatory, such as fasting the month of Ramadan and zakat. What has been proved by misgiving evidence, such as Ahad, and measurement, such as Witr praying, it is obligatory. This distinction has an effect on them, namely, that the person who denies the imposition is infidel, but who denies the duty is not infidel, and that the punishment of those who leave the duty is less than the punishment of those who leave the imposition.

Sufficientness: What is to fill the need and reach the desired ${ }^{(6)}$.

Fall down: Not demanding. It is said that he waives his right in the case, means: he stopped claiming it ${ }^{(7)}$.

By doing: by working, it is said: to have done the thing: to work it ${ }^{(8)}$.

Some: the some is contrastive to the all ${ }^{(9)}$.

Competent: He is the sane, adult Muslim, in which the conditions of the commissioning: the mind, the attainment and safety of the symptoms and contraindications are available, he is called convicted ${ }^{(10)}$.

\section{Branch (3): The total meaning of the rule.}

The imposition of the obligation in terms of those who address it is divided to: individual imposing, which is what Allah asked to do from every particular competent (himself) as a firm request, either it was proven by definitive evidence, as in Hanafi opinion, or proven by any means to the opinion of the public - so that he is obliged to do it, and he is punished for leaving it, such as prayer, fasting, and kinship cordiality. It is called individual because the act attached to the imposition attributed to the self as that the act is intentional, this imposition is required to do it from each competent in particular, so that his innocent is proven only by his action ${ }^{(11)}$. The second division is the sufficiency duty, which is what the Allah asked to do from a group of competent, not from any particular one. 
It is called by this name because it is attributed to the sufficientness, if it done by any competent, it is sufficient to drop the sin of the rest, and if it does not done by any one, all of them will be sinned, because the matter is intended to do regardless of who does it, contrary to the individual imposition. Al-Suyuti said: "The sufficiency duties are holistic matters related to religious or worldly interests. The matter is not expected unless it is obtained, so Allah require Muslims to do it, not to assign one of them in particular, it differs from the collective imposition which means that if it is done by those who are sufficient, the embarrassment is fell to the rest" ${ }^{(12)}$.

\section{Branch (4): An application of the rule: Ruling on burying the deceased}

The Ruling of burying the deceased is a sufficiency duty, if some do it, the sin will be fell to the rest. Al-Nawawi said: "The burial of the dead is a sufficiency duty by consensus" ${ }^{(13)}$.

\section{Demand (2)}

\section{The second rule: Favored actions which are optional are obedience.}

It includes four branches:

\section{Branch (1): Who agreed the consensus of the rule?}

The consensus on this rule was told by a number of fundamentalists, including Al-Juwaini. He said: "We said: what indicates that is the agreement of the whole nation that the favored actions are obedience" ${ }^{(14)}$. He also said: "... It was decided by the agreement of the nation to designate the delegate as an obedience" (15). Al-Amidi said: "Demonstrators argued that the act of the favored actions are called an obedience in agreement" (16).

\section{Branch (2): Explaining the vocabularies of the rule.}

Favored actions: the source is scar, and scarring is that the man deputes people to order, or war, or aid, which means that he calls them, so that they respond and accelerate, and the meaning of (scarred the people to order scold them) is called them and urged them and assigned to him: Hurry up ${ }^{(17)}$. Conventionally the meaning of favored actions (Mandoob) is what required to do something from sharia with no fault of leaving it at all ${ }^{(18)}$.

Obedience: obey in language: Ibn Zakaria said: "it is true origin indicates the docility and control. It is said that he obeys to him if he is saved with him and goes on to do so" ${ }^{(19)}$. Conventionally the meaning of obedience is to do what is required, not to do what is forbidden, and disobedience other than ${ }^{(20)}$.

\section{Branch (3): The total meaning of the rule.}

The act of the favored actions is in compliance with the command of Allah Almighty provided that it is desire and contentment, and without coercion.

\section{Branch (4): An application of the rule: Ruling on Tahajjud prayer, or night prayer.}

Prayer of tahajjud or night prayer is one of the non-stressed supererogatory practices, it is one of the best prayers after obligatory prayers. The Messenger of Allah (peace and blessings of Allah be upon him) said: "The best prayer after the obligatory prayer is the night prayer" (21). Its ruling is a favored action. Al-Nawawi said: "The voluntary night prayer is a stressed supererogation, and the signs of the Qur'an, Sunnah and the consensus of the nation have coincided it" ${ }^{(22)}$.

Demand (3)

\section{The second rule: Continuation of assignment to the Day of Resurrection.}

It includes four branches:

\section{Branch (1): Who agreed the consensus of the rule?}

The consensus on this rule was told by a number of fundamentalists including Al-Ghazali. He said: "The ancestors of the nation are united continuation of assignment to the day of resurrection" ${ }^{(23)}$. Ibn Hazm said: "The proof that the meaning of this response is to the Qur'an, and the news of the Messenger of Allah peace be upon him, because the nation is unanimous that this speech addressed to us, and to all who is created and his soul in his body to the day of resurrection of paradise and people, Such as its approach to those who were at the time of the Messenger of Allah peace be upon him, and everyone who came after him peace be upon him and before us, and no difference" (24).

\section{Branch (2): Explaining the vocabularies of the rule.}

Continuation: Existence and survival ${ }^{(25)}$.

Assignment: It is a matter of what is difficult ${ }^{(26)}$, and it is conventionally: obligating the requisite of sharia speech ${ }^{(27)}$. To: A preposition, indicating the end of the temporal goal.

The Day of Resurrection: is the last day, and it is called the Day of Judgment for the great things that are done in it, including the people standing up to the lord of the worlds (Allah). 


\section{Branch (3): The total meaning of the rule.}

The speech of Sharia is general in all times of compliance and abstention, constant, does not change nor fall from the present or from those who will exist if the conditions of the mandate of attainment and reason, and the absence of impediments to the day of resurrection. Based on this, the saying: "The provisions of Sharia came down to whom addressed in particular, so that who follow them is not necessary to apply these provisions, because of the difference of case" is invalid, because it is an invitation to destroy the law of God Almighty, and contrary to this rule.

Branch (4): An application of the rule: Ruling on the inheritance of the divorced in a revocable divorce if her husband died in the waiting period

If a man divorced his wife in a revocable divorce, and he or she died before the end of her waiting period, then the living one inherits the other unanimously. Ibn Hazm said: "They agreed that the revocable divorced woman, inherits her husband and he inherits her as long as she was in the waiting period" ${ }^{(28)}$. This is a general judgment at all times that does not change or convert to the day of resurrection.

Demand (4)

The second rule: The infidels do not assigned after their Islam of the acts of their infidelity.

It includes four branches:

\section{Branch (1): Who agreed the consensus of the rule?}

The consensus on this rule was told by a number of fundamentalists, including Al-Razi, who said: "The violators protested in two things: one is that: if the infidel had to be prayed, it would be in his infidelity or after that. The first is invalid, because doing prayer in the case of infidelity is prohibited, and abstention is not prescribed. The second is invalid for our consensus that if the infidel became Muslim, he is not commanded to make up for what he missed during the time of infidelity ${ }^{(29)}$. Ibn Taymiyah said: "... what left by the original infidel of duty, such as prayer, zakat and fasting, it should not be made up for after Islam unanimously" ${ }^{(30)}$. Al-Mardini said: "If you say that after Islam, then it is also for the consensus of the scholars that the infidel should not be ordered after Islam for what he missed in the case of infidelity, and he cannot be held accountable for the forbidden things that he has done ${ }^{(31)}$.

\section{Branch (2): Explaining the vocabularies of the rule.}

Infidels: The gathering of infidel, who does not believe in Allah or Muhammad, the Messenger of Allah, or who denies what is known from Islam necessarily, or detracts from the position of God or the divine message ${ }^{(32)}$. The polytheist also follow the infidel, with the warning that there is a difference between infidelity and polytheism, not every infidel is a polytheist, but every polytheist is an infidel, there is an infidel, not with a polytheist, but with defiance, atheism, or arrogance, or by breaking the two declarations of faith.

Not: A negation character based on silence has no place of expression.

Assigned: assignment: It is a matter of what is difficult ${ }^{(33)}$, and it is conventionally: obligating the requisite of sharia speech $^{(34)}$.

After: An adverb of time, indicates the delay of something about another in its time ${ }^{(35)}$.

Their Islam: Their entrance in Islam.

Of: A preposition, indicating the type statement.

Acts: Something have been done.

Their infidelity: When they described as infidels.

Branch (3): The total meaning of the rule.

The infidels are those who don't believe in Islam, either they:

a) Fighters: the infidels who hold the nationality of the infidel state fighting Muslims ${ }^{(36)}$.

b) Or Confederates: Who had been concluded a peace treaty or a non-aggression treaty with them or their state ${ }^{(37)}$.

c) Or Fiduciary: Who had been given temporary security to themselves, their money, their symptoms and their religion ${ }^{(38)}$.

d) Or Invectives: Non-Muslim citizens, had been given a pledge in the state of Islam, to preserve their lives and money and not to prejudice their religions ${ }^{(39)}$.

e) Or Neutrals: Who do not take sides, or who refuse to adopt one of two opposing ideas, do not support one another, as their peaceful relationship with the warring parties ${ }^{(40)}$.

All of these who entered Islam, do not have to make up for what is missed by the obedience to the case of infidelity, as Islam negates what preceded it.

Branch (4): An application of the rule: Ruling on infidels making up what he missed of devotion acts 
He does not have to make up for his missed of devotion acts. Ibn Qudamah said: "As for the infidel, if he is an original, he does not have to make up what he has left from the devotion acts in the event of his infidel, with no difference that we know" ${ }^{(41)}$.

Demand (5)

The second rule: The initiator to the ordered manners act in the absolute command comes out the custody of assignment.

It includes four branches:

\section{Branch (1): Who agreed the consensus of the rule?}

The consensus on this rule was told by a number of fundamentalists, including Al-Shirazi, who said: "They said: We are unanimously agreed that the act in the previous time is an absolute and an obedience, in which the imposition of obedience falls, and compliance is achieved, and who claims that in the second time the same act is an absolute and an obedience becomes a complied, he must have the evidence" ${ }^{42)}$. Al-Amidi, when he spoke about what is required of the absolute order to expedite the act of the ruler or not, he said: "... Waqfiya have stopped, but some of them said: the stop is in the backside: Is he complying or not? As for the initiator, he is strictly bound, but is he guilty of delay? They differed in this: Some of them said in the sin, which is the choice of the imam of the two Holy Mosques, and some of them did not sin, and some of them stopped in the initiator also, and contrary to that consensus predecessor" ${ }^{(43)}$. AlArmawi said: "... The most extreme: they who stopped in the initiator and late in that he is complying or not? They also attributed to breaching the consensus of the predecessors, they were categorized that the initiator was quick to comply, and amounts in obedience" ${ }^{(44)}$.

\section{Branch (2): Explaining the vocabularies of the rule.}

Initiator: Accelerator ${ }^{(45)}$.

To: A preposition, indicating the end of the temporal goal.

Act: The act is creating something from work and others ${ }^{(46)}$.

Authorized: required to do.

In: A preposition, means: agglutination.

The absolute command: the abstract command of clues ${ }^{(47)}$.

Come out: Get rid of ${ }^{(48)}$.

About: A preposition, means: the excess.

Custody: fulfillment ${ }^{(49)}$.

Assignment: a source of assign, and the assignment means the order of what is difficult to you ${ }^{(50)}$, and conventionally it means the obligation of sharia speech supplication ${ }^{(51)}$.

\section{Branch (3): The total meaning of the rule.}

Who hastened to do what is required from him by the qualities and conditions that Allah ordered in the matter which is hasn't a presumption - and the presumption of the fundamentalists, is: what accompanies the evidence to indicate the meaning of it or strengthens its significance or prove ${ }^{(52)}$ - indicates the time or place to do already, then he complied the matter, and obtained the recompense, and the judiciary is dropped.

\section{Branch (4): An application of the rule: Ruling on speeding up the expiation for wrongful killing}

Whoever kills a forbidden soul wrongly, it follows that this leads to two things:

The first: the extenuating blood money, on the rational of the wrong killer.

Second: Atonement, which is one of two things: the first is to manumit a believing man, and this is impossible in our time for the disappearance of bondage and slavery. The second thing is to fast two consecutive months for someone who cannot find manumitting a believing man, and this is what is needed at this time. The commandment to fast is absolute and unrestricted at any given time. Al-Nawawi said: With regard to the atonement, if it is non-aggression, such as the atonement of wrong killing and oath in some matters, it is on the laxity without controversy, because he is excused ${ }^{(53)}$. If the wrong killer fasts by fasting for two consecutive months, then he obeyed the command of Allah Almighty, and he was innocent, and fulfilled what he is commanded to do.

\section{Demand (6)}

The second rule: It is not permissible for the assigned person to delay the ordered act to the time, that if it had been done, he would have exceeded it.

It includes four branches: 


\section{Branch (1): Who agreed the consensus of the rule?}

The consensus on this rule was told by a number of fundamentalists, including Al-Rahwani, when he spoke about the question of those who say of urgency. He said: They said: Sixth, if the delay is lawful, then it must be for a length of time, otherwise, it may delay it without restriction, so it is not a duty. The length of time must be restricted, otherwise, the assignment of preventing such a delay would be a duty of hopeless assignment, and the time specification to be notified of the matter, and no evidence appoint it from an outside, because they agreed that it is not permissible to delay it for a time if he did not engage in it he would miss it ${ }^{(54)}$.

\section{Branch (2): Explaining the vocabularies of the rule.}

It is not permissible to delay the ordered act: It is not permissible to postpone and delay the work that is required to be done.

To: A preposition, indicating the end of the temporal goal.

Time: A period of history, as long as the order is long or short ${ }^{(55)}$.

If: A non-conclusive character of the clause that is stating the abstention of the answer to avoid the condition.

Had been done: Someone did it.

Exceed: The time to do it had gone ${ }^{(56)}$.

Assigned person: $\mathrm{He}$ is a Muslim, a sane, adult, in which the conditions of the commissioning of the mind, the attainment, safety of the symptoms, and contraceptives of legitimacy are available, he is called a convicted person ${ }^{(57)}$.

\section{Branch (3): The total meaning of the rule.}

The acts to be performed by the assigned person are divided, in terms of performance time and period, into two parts: The first is temporary, which is either an extended duty, which is the act that Allah demanded from the assigned, whose performance are a firm demand at a time that is enough to do and to do another duties of this type ${ }^{(58)}$, such as the obligatory prayer time, which is valid for the performance of non-obligatory prayers, or a strict duty, which is the act that the street demanded from the assigned, a firm and specific request at a time that is enough to do that only, without capability to do another duties of this type ${ }^{(59)}$, such as fasting on the day of Ramadan, the time for fasting is not sufficient for doing anything else with it from the fasting type. The second is a duty that is not temporary, which is the absolute duty. This is what Allah demanded of the assigned to make a firm request, and did not specify a specific time to do it, like Hajj for those who see it as obligatory for laxity, also the oaths expiations, which are absolutely obligatory, and the wise street did not specify a certain time that the assigned must perform in it, but if the assigned thinks that if he does not fulfill the absolute duty he will not be able to do it, then he will be forbidden to delay the act, and he must do it as soon as he can.

\section{Branch (4): Ruling on fulfilling the absolute vow, if it is presumed that he is not able to do it if he delayed doing} it.

The absolute vow is to adhere doing something as means of nearness to Allah, without commenting on the purpose of it, and without the motive of adversity or anger, as if to say: I has to fast on Thursday to the sake of mercy to Allah ${ }^{(60)}$. The ruling on fulfilling the absolute vow is obligatory for the Prophet (peace and blessings of Allah be upon him) to say: "Whoever vows to obey Allah, then he will obey him, and whoever vows to disobey Allah will not disobey him" (61). Ibn Hajar said: "The hadeeth is explicit in the matter of fulfilling the vow if it is in obedience, and in the prohibition on leaving it if it is in disobedience" (62). The vow may delay it as long as the opportunity is possible, and in the most likely way he is able to fulfill the vow ${ }^{(63)}$.

\section{Conclusion}

\section{The most important results through research}

Praise be to God that His grace is righteousness, peace and blessings be upon the master of the first people and others, Mohammed bin Abdullah, and who walked on his approach to the Day of Judgment. I can summarize the most important results in this research as follows:

First: the fundamental rules are holistic provisions, reached to derive legitimacy provisions, or weighting between the conflicting jurisprudence.

Second: the third source of fundamentalism derive rules is consensus.

Third: fundamentalists have commendable efforts in clarifying the agreed fundamental rules.

Fourth: there are many agreed fundamental rules, and I have extrapolated fundamental books and extracted six rules related to Sharia rulings, I explained its vocabulary, clarified its general meaning, and mentioned one application on each rule. 
I ask Allah to accept this work, and make it in the balance of my good deeds on the Day of Judgment. Allah is the conciliator, and the guide to the right path.

\section{Margins:}

(1) Al-Zarkashi, Mohammad, The Surrounding Moon, 7/322.

(2) Ibn Zakaria, Ahmad, Dictionary of Language Standards, p.812.

(3) Ibn Al-Najjar, Mohammad, Explanation of the Bright Planet, 1/351-352.

(4) Al-Baidhawi, Abdullah, Access to Knowledge Assets Approach, p.55.

(5) Al-Shashi, Ahmad, The Origins of Al-Shashi, p.379.

(6) Redha, Ahmad, Language Board Dictionary, 5/87.

(7) Al-Karmi, Hasan, The Guide to Arab Language, 4/56.

(8) Redha, Ahmad, Language Board Dictionary, 3/429.

(9) Al-Karmi, Hasan, The Guide to Arab Language, 4/56.

(10) Sano, Qutb, Jurisprudence Terms Dictionary, p.440.

(11) Al-Namla, Abdul-Kareem, The Expanded Duty of Fundamentalists, P.110.

(12) Al-Suyuti, Abdul-Rahman, The Analogies and Isotopes in the Rules and Branches of the Shafia's Jurisprudence, p. 410 .

(13) Al-Nawawi, Yahya, Book of Total: Polite Explanation, 5/244.

(14) Al-Juwaini, Abdul-Malik, The Summary in the Fundamentals of Jurisprudence Book, 1/258.

(15) Al-Juwaini, Abdul-Malik, The Summary in the Fundamentals of Jurisprudence Book, 1/261.

(16) Al-Amidi, Ali, The Accuracy in Fundamentals of Provisions, 1/91.

(17) Ibn Mandhour, Arab tongue, 14/221.

(18) Al-Amidi, Ali, The Accuracy in Fundamentals of Provisions, 1/91.

(19) Ibn Zakaria, Ahmad, Dictionary of Language Standards, p.603.

(20) Ibn Hajar, Ahmad, Fath al-Bari in Explaining Sahih Bukhari, 15/4.

(21) Hajjaj, Muslim, Sahih Muslim, Book of Fasting, Virtue Muharram Fast section, Hadith No: 2755, p. 473, and Al-Sijistani, Sulaiman, Sunan Abi Dawood, The Book of Fasting, chapter on the Fast of Muharram, Hadith no. 2429, and Al-Tirmidhi, Muhammad, Sunan al-Tirmidhi, the book of Prayer, the chapter on the Virtue of the Night Prayer, Hadith No. 440, p. 351, and Al-Nasa'i, Ahmad, Sunan Al-Nasa'i (Al-Mujtaba), The Book of Night Prayer and the Daytime Volunteer, Hadith no. 1613, p. 464, and Ibn Hanbal, Ahmad, Musnad, hadith no. (8534), 14/215.

(22) Al-Nawawi, Yahya, Book of Total: Polite Explanation, 3/535.

(23) Al-Ghazali, Mohammad, Al-Mustafa in Assets Science, 1/352-353.

(24) Ibn Hazm, Ali, The Accuracy in Fundamentals of Provisions, 1/96.

(25) Al-Karmi, Hasan, The Guide to Arab Language, 2/79.

(26) Al-Zubaidi, Mohammad, Bride's Crown of the Dictionary Jewels, 12/465.

(27) Ibn Al-Najjar, Mohammad, Explanation of the Bright Planet, 1/483.

(28) Ibn Hazm, Ali, Consensus Rankings, P.181.

(29) Al-Razi, Mohammad, The Incomings of Jurisprudence, 2/245.

(30) Ibn Taymiyah, Ahmad, Total Fatwas of Sheikh al-Islam Ahmad bin Taymiyah, 22/7.

(31) Al-Mardini, Mohammad, The Prostitutes in Solving the Words of the Papers, P.127.

(32) Qalaa-Jee, Mohammad, and Qunaibi, Hamed, Jurists language dictionary, p.375.

(33) Al-Zubaidi, Mohammad, Bride's Crown of the Dictionary Jewels, 12/465.

(34) Ibn Al-Najjar, Mohammad, Explanation of the Bright Planet, 1/483.

(35) Al-Hamad, Ali, and Al-Zoubi, Yousef, Dictionary of Arabic Grammatical Tools, P.114.

(36) Qalaa-Jee, Mohammad, and Qunaibi, Hamed, Jurists language dictionary, p.178.

(37) Qalaa-Jee, Mohammad, and Qunaibi, Hamed, Jurists language dictionary, p.438.

(38) Qalaa-Jee, Mohammad, and Qunaibi, Hamed, Jurists language dictionary, p.426.

(39) Qalaa-Jee, Mohammad, and Qunaibi, Hamed, Jurists language dictionary, p.214.

(40) Fattani, Ismail, The Difference between the Two Parts and its Effect on the Provisions of the Disputes and Transactions, P.137.

(41) Ibn Qudamah, Abdullah, The Enriched, 2/48.

(42) Al-Shirazi, Ibrahim, Lominous Explanation, 1/241.

(43) Al-Amidi, Ali, The Accuracy in Fundamentals of Provisions, 2/31.

(44) Al-Armawi, Mohammad, The Access End to Assets Knowing, 3/955.

(45) Ibn Zakaria, Ahmad, Dictionary of Language Standards, p.100, and Redha, Ahmad, Language Board Dictionary, $1 / 253$. 
(46) Ibn Zakaria, Ahmad, Dictionary of Language Standards, p.821.

(47) Al-Namla, Abdul-Kareem, The Polite in the Science of Comparative Jurisprudence, 3/1367.

(48) Omar, Ahmad, Contemporary Arabic Dictionary, 1/625.

(49) Redha, Ahmad, Language Board Dictionary, 4/231.

(50) Al-Zubaidi, Mohammad, Bride's Crown of the Dictionary Jewels, 12/465.

(51) Ibn Al-Najjar, Mohammad, Explanation of the Bright Planet, 1/483.

(52) Al-Mubarak, Mohammad, The Presumptions of the Fundamentalists, 1/68.

(53) Al-Nawawi, Yahya, Book of Total: Polite Explanation, 3/74-75.

(54) Al-Rahwani, Yahya, Masterpiece Charge in a Brief of the Soul Ultimate Explanation, 3/36.

(55) Omar, Ahmad, Contemporary Arabic Dictionary, 3/2477.

(56) Omar, Ahmad, Contemporary Arabic Dictionary, 1/1749.

(57) Sano, Qutb, Jurisprudence Terms Dictionary, p.440.

(58) Al-Namla, Abdul-Kareem, The Expanded Duty of Fundamentalists, P.104.

(59) Al-Namla, Abdul-Kareem, The Expanded Duty of Fundamentalists, P.107.

(60) Al-Khun, Mustafa and Al-Buqa, Mustafa, and Al-Shourbaji, Ali, the Methodical Jurisprudence on the Doctrine of Imam Shaf'i, 1/459.

(61) Al-Bukhari, Mohammad, Sahih Al-Bukhari, the Book of Faith and Vows, the section of vows in obedience, Hadith No. 6969, 2/611, and Ibn Hanbal, Ahmad, Al-Musnad, hadith no. 24075, 40/86.

(62) Ibn Hajar, Ahmad, Fath al-Bari in Explaining Sahih Bukhari, 13/441.

(63) Al-Zuhaili, Mohammad, the Adopted in the Shaf'i Jurisprudence, 2/510.

\section{References}

Al-Amidi, Ali bin Mohammad, The Accuracy in Fundamentals of Provisions, Dar al-Fikr, Beirut, without mentioning the edition, $1401 \mathrm{HJ}-1981 \mathrm{AD}$.

Al-Armawi, Mohammad bin Abdul-Raheem, The Access End to Assets Knowing, Investigation of Saleh bin Sulaiman Al-Yousef, Saad bin Salem Al-Sarih, Nizar Mustafa Al-Baz Library, Makkah, Second Edition, 1429 HJ - 2007 AD.

Al-Baidhawi, Abdullah bin Omar, Access to Knowledge Assets Approach, Verified, Introduced to, and Mystery Explained by Shaaban Mohammed Ismail, Dar Ibn Hazm, Beirut, First Edition, 1429 HJ - 2008 AD.

Al-Bukhari, Mohammad bin Ismail, Sahih Bukhari, Hadiths Documented and Commented on by Izzeddin Dhelly, Imad Al-Tayyar, and Yaser Hasan, AL-Resala Company for Publication, Beirut, new print, 1433 HJ- 2012 AD.

Al-Ghazali, Mohammad bin Mohammad bin Mohammad Al-Ghazali, Al-Mustafa in Assets Science, Investigation and Commentary of Mohammad Sulaiman Al-Ashqar, Al-Resala Foundation, Beirut, First Edition, 1417 HJ $1997 \mathrm{AD}$.

Al-Hajjaj, Muslim, Sahih Muslim, Noticed by Yaser Hasan, Izzeddin Dhelly, and Imad Al-Tayyar, Al-Resala Company for Publication, Beirut, First Edition, 1433 HJ- 2012 AD.

Al-Hamad, Ali, and Al-Zoubi, Yousef, Dictionary of Arabic Grammatical Tools, Dar Al Amal, Irbid, Second Edition, 1414 HJ - 1993 AD.

Al-Juwaini, Abdul-Malik bin Abdullah bin Yousef, The Summary in the Fundamentals of Jurisprudence, Investigation of Abdullah Gulm AL-Nepali, and Shubair Ahmed Al-Omari, Dar al-Bashaer Islamic, Beirut, Second Edition, 1428HJ - 2007 AD.

Al-Karmi, Hasan Saeed, The Guide to Arab Language, Lebanon Dar for Printing and Publishing, Beirut, First Edition, $1411 \mathrm{HJ}-1991 \mathrm{AD}$.

Al-Khun, Mustafa and Al-Buqa, Mustafa, and Al-Shourbaji, Ali, The Methodical Jurisprudence on the Doctrine of Imam Shaf'i, Dar Al-Qalam, Damascus, and Dar Al-Shamiya, Beirut, Seventh Edition, 1427 HJ - 2006 AD.

Al-Mardini, Mohammad bin Osman bin Ali, The Prostitutes in Solving the Phrases of the Papers, Introduced, Verified, and Commented on by Abdul-Kareem bin Ali bin Mohammad Al-Namla, Al-Rashed Library, Riyadh, First Edition, 1415 HJ - 1994 AD.

Al-Mubarak, Mohammad bin Abdul-Aziz, The Presumptions of the Fundamentalists, Imam Mohammad Bin Saud Islamic University, Riyadh, First Edition, 1426 HJ - 2005 AD.

Al-Namla, Abdul-Kareem bin Ali bin Mohammad, The Expanded Duty of Fundamentalists, Al-Rushd Library, Riyadh, First Edition, 1414 HJ - 1993 AD.

Al-Namla, Abdul-Kareem bin Ali bin Mohammad, The Polite in the Science of Comparative Jurisprudence, AlRushd Library, Riyadh, First Edition, 1420 HJ - 1999 AD. 
Al-Nasa'i, Ahmad bin Sho'aib, Sunan Al-Nasa'i (Al-Mujtaba), Hadiths were Documented and Commented on by Yasser Hassan, Izzeddin Dhelly, and Emad Al-Tayyar, Al-Resala Publishers, Beirut, First Edition, 1435 HJ 2014 AD.

Al-Nawawi, Yahya bin Sharaf, Book of Total: Polite Explanation, Verified, Commented upon and Completed after its Diminution by Mohammad Najib Al-Mutai'i, Library of Guidance, Jeddah, without mentioning the edition, and the date of publication.

Al-Rahwani, Yahya bin Mousa, Masterpiece Charge in a Brief of the Soul Ultimate Explanation, Study and Investigation: Yousef Al-Akhdar Al-Qayyim, Dar of Research for Islamic Studies and Heritage Revival, Dubai, First Edition, 1422 HJ - 2002 AD.

Al-Razi, Mohammad bin Omar bin Al-Husain, The Incomings of Jurisprudence, Study and Investigation of Taha Jaber Al-Alwani, Al-Resala Foundation, Beirut, Second Edition, 1412HJ - 1992 AD.

Al-Shashi, Ahmad bin Mohammad bin Ishaq, The Origins of Al-Shashi, Arabic Book Dar, Beirut, without mentioning the edition, $1402 \mathrm{HJ}-1982 \mathrm{AD}$.

Al-Shirazi, Ibrahim bin Ali bin Yousef, Lominous Explanation, Verified, Introduced to, and Stated its Catalogs by Abdul-Majeed Turki, Dar Al-Gharb Al-Islami, Tunisia, First Edition, 1988 AD.

Al-Sijistani, Sulaiman bin Al-Ashaath, Sunan Abi Dawood, Hadiths were Documented and Commented on by Yasser Hassan, Izzeddin Dhelly, and Emad Al-Tayyar, Al-Resala Publishers, Beirut, First Edition, 1434 HJ - 2013 $\mathrm{AD}$.

Al-Suyuti, Abdul-Rahman bin Abi Bakr bin Mohammad, The Analogies and Isotopes in the Rules and Branches of the Shafia's Jurisprudence, Scientific Books Dar, Beirut, First Edition, 1399 HJ - 1979 AD.

Al-Tirmidhi, Muhammad bin Isa bin Surah, Sunan Al-Tirmidhi, Hadiths were Documented and Commented on by Izzeddin Dhelly, Emad al-Tayyar, and Yasser Hassan, Al-Resala Company for Publication, Beirut, the First Edition, $1432 \mathrm{HJ}-2011$ AD.

Al-Zarkashi, Mohammad bin Bahader, The Surrounding Moon, Hadiths were Verified and Documented by a Committee of Scholars of Al-Azhar, Dar al-Kutbi, Cairo, First Edition, 1414 HJ - 1994 AD.

Al-Zubaidi, Mohammad, Bride's Crown of the Dictionary Jewels, Study and Investigation of Ali Sheery, Dar Al Fikr, Beirut, First Edition, 1414 HJ - 1994 AD.

Al-Zuhaili, Mohammad, The Adopted in the Shaf'i Jurisprudence, Dar Al-Qalam, Damascus, Second Edition, 1431 $\mathrm{HJ}-2010$ AD.

Fattani, Ismail Lutfi, The Difference between the Two Parts and its Effect on the Provisions of the Disputes and Transactions, Dar Al-Salam, Cairo, First Edition, 1410 HJ - 1990 AD.

Ibn Al-Najjar, Mohammad bin Ahmad bin Abdul-Aziz, Explanation of the Bright Planet, Verified by Mohammad alZuhaili, Nazih Hammad, Obeikan Library, Riyadh, without mentioning the edition, 1413 AH - 1993 AD.

Ibn Hajar, Ahmad bin Ali, Fath al-Bari in Explaining Sahih Bukhari, Dar al-Fikr, Beirut, without mentioning the edition, $1414 \mathrm{HJ}$ - 1993 AD.

Ibn Hanbal, Ahmad, Musnad Imam Ahmad bin Hanbal, Verification Supervision of Shoaib Arnaout, Al-Resala Foundation, Beirut, Third Edition, 1436 HJ - 2015 AD.

Ibn Hazm, Ali bin Ahmad bin Saeed, The Accuracy in Fundamentals of Provisions, Scientific Books Dar, Beirut, First Edition, 1405 HJ - 1985 AD.

Ibn Hazm, Ali bin Saeed, Consensus Rankings, Tended by Hassan Ahmed Asbar, Dar Ibn Hazm, Beirut, First Edition, 1419 HJ - 1998 AD.

Ibn Mandhour, Arab tongue, Dar Sader, Beirut, First Edition, 2000 AD.

Ibn Qudamah, Abdullah bin Ahmad, The Enriched, Investigation of Abdullah bin Abdul-Mohsen Al-Turki, AbdulFattah Mohammad al-Hilu, World Books Dar, Riyadh, Third Edition, 1417 HJ - 1997 AD.

Ibn Taymiyah, Ahmad bin Abdul-Haleem, Total Fatwas of sheikh al-Islam Ahmad bin Taymiyah, Gathering and Arrangement of Abdul-Rahman bin Mohammad bin Qasim, Assisted by his son Mohammad, Dar Al-Arabia Press, Beirut, Photocopy of the First Edition, 1398 HJ.

Ibn Zakaria, Ahmad bin Fares, Dictionary of Language Standards, Noticed by Mohammad Awad and Fatima Mohammad Aslan, Dar Arab Heritage Revival, Beirut, First Edition, 1422 HJ - 2001 AD.

Omar, Ahmad Mukhtar, Contemporary Arabic Dictionary, World of Books, Cairo, First Edition, 1429 HJ - 2008 AD.

Qalaa-Jee, Mohammad Rawwas, and Qunaibi, Hamed, Jurists language dictionary, Dar Al-Nafais, Beirut, Second Edition, 1408 HJ - 1988 AD.

Redha, Ahmad, Language Board Dictionary, Library of Life, Beirut, without mentioning the edition, 1377 HJ - 1958 $\mathrm{AD}$.

Sano, Qutb Mustafa, Jurisprudence Terms Dictionary, Dar of Contemporary Fikr, Beirut, Dar Al-Fikr, Damascus, First Edition, 1420 HJ - 2000 AD. 